\title{
Animal performance and milk fatty acid profile of dairy goats fed diets with different unsaturated plant oils
}

\author{
A. L. Martínez Marín, ${ }^{*}$ P. Gómez-Cortés, $\dagger^{1}$ A. G. Gómez Castro, ${ }^{*}$ M. Juárez,† L. M. Pérez Alba, ${ }^{\star}$ M. Pérez \\ Hernández, ${ }^{*}$ and M. A. de la Fuente ${ }^{2}$ \\ *Departamento de Producción Animal (Universidad de Córdoba), Ctra. Madrid-Cádiz s/n, Campus de Rabanales, 14014 Córdoba, Spain \\ †Instituto de Investigación en Ciencias de la Alimentación (CSIC-UAM), Nicolás Cabrera, 9. Universidad Autónoma de Madrid, 28049 Madrid, \\ Spain
}

\section{ABSTRACT}

The effect of supplementing a basal diet with 1 of 3 plant oils on productive efficiency and milk fatty acid composition was studied in dairy goats. Sixteen Malagueña goats were used in a $4 \times 4$ Latin square experiment with 21-d periods and 4 goats per treatment. The basal diet comprised $30 \%$ alfalfa hay and $70 \%$ pelleted concentrate. Experimental treatments were control (basal diet without added oil) and the basal diet supplemented with $48 \mathrm{~g} / \mathrm{d}$ of high oleic sunflower oil (HOSFO), regular sunflower oil (RSFO), or linseed oil (LO). Dry matter intake and body weight were not affected by treatments. Milk production was higher in HOSFO treatment and milk fat content was higher in RSFO and LO treatments, although no differences in milk energy production or milk renneting properties were found. The RSFO and LO treatments increased the proportion of vaccenic acid in milk fat more so than the HOSFO diet, and rumenic acid followed the same pattern. The content of trans10-18:1 remained low in all experimental diets $(<0.7 \%$ of total fatty acid methyl esters) although HOSFO and RSFO diets increased it. The variations in the fatty acid profiles observed with the 4 diets, mainly the unsaturated fatty acid isomer contents, are extensively discussed. Compared with that in the control diet, the n-6:n-3 fatty acid ratio in milk fat substantially decreased with the LO, increased with RSFO, and did not change with HOSFO. The addition of moderate amounts of LO to the diets of dairy goats has favorable effects on milk fatty acid composition from the point of view of the human consumer, without negative effects on animal performance.

Key words: plant oil, fatty acid profile, goat milk

Received May 25, 2011.

Accepted July 22, 2011.

${ }^{1}$ Present address: Division of Nutritional Sciences, Cornell University, Ithaca, NY 14853.

${ }^{2}$ Corresponding author: mafl@if.csic.es

\section{INTRODUCTION}

Increasing the lipid content of ruminant diets may have multiple benefits: (1) to increase the energy concentration of the ration to meet requirements of highproduction animals; (2) to decrease the risk of ruminal acidosis and milk fat depression when low-forage diets are fed; and (3) to modify the type and amount of fatty acids (FA) in animal products (Chilliard and Ollier, 1994). The last factor is especially important as a means to enhance the healthy properties of animal foods or decrease the potential negative effects of specific FA to the human consumer.

Feeding fat sources to dairy ruminants can modify the content of some FA in milk fat (Chilliard et al., 2000). Decreasing medium-chain saturated fatty acids (SFA) and the n-6:n-3 ratio of polyunsaturated fatty acids (PUFA; Simopoulos, 2008), and increasing vaccenic acid and some conjugated linoleic acid (CLA) isomers (Field et al., 2009) would be favorable in terms of the health of the human consumer. However, modification of the FA profile in ruminant products is not always positive to the consumer: an increase of $\operatorname{trans}(\boldsymbol{t}) 10-18: 1$ may occur in milk fat (Chilliard and Ferlay, 2004), and Combe et al. (2007) noted the cardiovascular risk posed by the increased intake of this trans monounsaturated fatty acid (MUFA).

In addition, and with regard to animal performance, some trans isomers may depress milk fat synthesis in the udder (Shingfield and Griinari, 2007). In Mediterranean countries, goat milk is mostly used in the manufacture of cheese, curd, and other fermented derivatives. Around $40 \%$ of Spanish goat milk is transformed into pure goat cheese (MARM, 2010). Milk efficiency for cheese making is related to the milk fat and protein contents, which in turn could affect milk renneting properties (Zumbo et al., 2004; Todaro et al., 2005). Furthermore, if feeding supplemental fat sources affects milk fat and protein contents, milk coagulation parameters could also be affected. The aim of this study was to determine which of 3 plant oils, with different degrees of unsaturation, added to a typical dairy goat 
ration would provide better results in terms of health properties of milk and animal performance.

\section{MATERIALS AND METHODS}

\section{Animals, Housing, and General Management}

The experiment was carried out in the premises of the Animal Production building of the University of Córdoba, in accordance with the Spanish regulation on experimental animals. Sixteen multiparous Malagueña goats (initially $72 \pm 26$ DIM and $45.9 \pm 3.7 \mathrm{~kg}$ of BW) were used. The animals were housed in a room at 24 $\pm 1^{\circ} \mathrm{C}$ and with $16 \mathrm{~h} / \mathrm{d}$ of light. They were placed in individual cages of $1.0 \times 1.4 \mathrm{~m}$ with a slatted floor and water and feeding troughs. Before the experiment, all animals were vaccinated against contagious agalactia, gangrenous mastitis, clostridium enterotoxemia, and hemorrhagic septicemia (Laboratorios Ovejero, León, Spain). The goats were machine milked and stripped out by hand once a day at $0830 \mathrm{~h}$. The diet was offered in 2 equal meals at 0930 and $1600 \mathrm{~h}$.

\section{Experimental Design and Diets}

A $4 \times 4$ Latin square with 4 goats per treatment was arranged. Each period lasted $21 \mathrm{~d}$ and the experimental treatments were as follows: basal diet (30\% alfalfa and $70 \%$ concentrate) with no added oil (control diet), and $48 \mathrm{~g} / \mathrm{d}$ of high oleic sunflower oil (HOSFO), regular sunflower oil (RSFO), or linseed oil (LO) added to the basal diet (Table 1).

\section{Measurements, Sample Collection, and Chemical Analysis}

Body weight of the animals was recorded to the nearest $0.1 \mathrm{~kg}$ at the beginning and at the end of each experimental period. Animals were weighed after the milking and before the morning meal.

Voluntary feed intake was recorded daily for each animal. Daily DMI was calculated as the difference between feed offered and orts. The ingredients of the diets were sampled at the beginning of each experiment and stored, along with the orts, at $-20^{\circ} \mathrm{C}$ until

Table 1. Ingredients, chemical composition, and nutritive value of the experimental diets and fatty acids supplied by the added oils

\begin{tabular}{|c|c|c|c|c|}
\hline \multirow[b]{2}{*}{ Item } & \multicolumn{4}{|c|}{ Treatment $^{1}$} \\
\hline & Control $^{2}$ & HOSFO & RSFO & $\mathrm{LO}$ \\
\hline \multicolumn{5}{|l|}{ Diet, g/d } \\
\hline Alfalfa hay & 500 & 500 & 500 & 500 \\
\hline Concentrate $^{3}$ & 1,200 & 1,200 & 1,200 & 1,200 \\
\hline High oleic sunflower oil ${ }^{4}$ & - & 48 & - & - \\
\hline Regular sunflower oil ${ }^{4}$ & - & - & 48 & - \\
\hline Linseed oil ${ }^{4}$ & - & - & - & 48 \\
\hline \multicolumn{5}{|l|}{ Chemical composition } \\
\hline DM, \% & 89.8 & 89.6 & 89.8 & 89.6 \\
\hline $\mathrm{CP}, \%$ of DM & 18.4 & 17.4 & 17.5 & 17.7 \\
\hline $\mathrm{NDF}, \%$ of DM & 26.9 & 25.8 & 25.5 & 25.5 \\
\hline $\mathrm{FAH}, \%$ of DM & 2.7 & 5.9 & 5.7 & 5.8 \\
\hline Ash, $\%$ of DM & 7.6 & 7.7 & 7.9 & 7.8 \\
\hline \multicolumn{5}{|l|}{ Nutritive value $^{6}$} \\
\hline ME, Mcal/kg of DM & 2.67 & 2.80 & 2.80 & 2.80 \\
\hline MP, $\mathrm{g} / \mathrm{kg}$ of $\mathrm{DM}$ & 123 & 119 & 119 & 119 \\
\hline \multicolumn{5}{|l|}{ Fatty acids from oil, $\mathrm{g} / \mathrm{d}$} \\
\hline $16: 0$ & - & 1.8 & 2.9 & 2.6 \\
\hline $18: 0$ & - & 1.4 & 2.0 & 1.8 \\
\hline cis-9-18:1 & - & 41.0 & 14.2 & 10.0 \\
\hline $18: 2 n-6$ & - & 2.7 & 27.9 & 8.0 \\
\hline $18: 3 n-3$ & - & - & - & 23.9 \\
\hline
\end{tabular}

${ }^{1}$ Control = diet with no added oil; HOSFO, RSFO, and LO = diets enriched with $48 \mathrm{~g} / \mathrm{d}$ of high oleic sunflower oil, regular sunflower oil, or linseed oil, respectively.

${ }^{2}$ Basal diet supplied 4.8, 0.7, 5.5, 14.2, and $3.0 \mathrm{~g} / \mathrm{d}$ of 16:0, 18:0, cis-9-18:1, 18:2n-6, and 18:3n-3, respectively, calculated according to INRA (2002).

${ }^{3}$ Composition (g/kg, as fed): maize, 375; barley, 374.9; soybean meal, 200; vitamin and mineral premix (Maxi Nutral Ovejas, Nutral, Madrid, Spain), 30; binder (Exal, Tolsa, Madrid, Spain), 20; antioxidant (Luctanox, Lucta, Barcelona, Spain), 0.1.

${ }^{4}$ Included in the respective concentrate.

${ }^{5}$ Fat by acid hydrolysis.

${ }^{6}$ Calculated from NRC (2007). 
analysis. The procedures of AOAC (2006) were used to measure DM in feeds and orts, and ash, CP, and fat by acid hydrolysis in feeds. Neutral detergent fiber was measured in feeds by using the method described by Van Soest et al. (1991). Samples of the 3 plant oils used were methylated with sodium methoxide/boron trifluoride, extracted with isooctane, and injected in a gas chromatograph (6890 N Network System, Agilent, Palo Alto, CA) with auto injector and fitted with a flame ionization detector. The profile of fatty acid methyl esters (FAME) was determined by split injection (1:50) onto a Supelco Wax semicapillary column $(30 \mathrm{~m} \times 0.53$ $\mathrm{mm}$ i.d., 1.00- $\mu \mathrm{m}$ film thickness; Supelco, Bellefonte, PA) using a programmed temperature method. Initial oven temperature was $175^{\circ} \mathrm{C}$. After $2 \mathrm{~min}$, oven temperature was increased at $8^{\circ} \mathrm{C} / \mathrm{min}$ to $235^{\circ} \mathrm{C}$ and then held for 8 min. Helium was the carrier gas, and the injector and detector were at $250^{\circ} \mathrm{C}$.

Four samples of milk were taken from each animal at d 21, 2 for milk composition and renneting properties (Milko-Scan FT120 and Formagraph, respectively, Foss Electric, Hillerød, Denmark) and the other 2 for FA analysis. Individual milk yield was recorded in the last $3 \mathrm{~d}$ of each experiment. Daily milk was weighed and expressed on a 24-h basis.

To analyze FA composition, milk fat was extracted following the procedure described by Luna et al. (2005). Separated lipids were stored in amber vials, blanketed with a stream of $\mathrm{N}_{2}$, and stored at $-20^{\circ} \mathrm{C}$ until analysis. Fatty acid methyl esters were prepared by basecatalyzed methanolysis of the glycerides (ISO-IDF, 2002a). Analysis of FAME in hexane was performed on a gas chromatograph (6890 N Network System, Agilent) with auto injector and fitted with a flame ionization detector. The FAME profile was determined by split injection (1:100) onto a CP-Sil 88 fused silica capillary column $(100 \mathrm{~m} \times 0.25 \mathrm{~mm}$ i.d., $0.20-\mu \mathrm{m}$ film thickness; Varian, Middelburg, the Netherlands) using a programmed temperature method. Initial oven temperature was $160^{\circ} \mathrm{C}$. After $80 \mathrm{~min}$, oven temperature was increased at $10^{\circ} \mathrm{C} / \mathrm{min}$ to $210^{\circ} \mathrm{C}$ and then held for 35 min. Helium was the carrier gas, and the injector and detector were at $250^{\circ} \mathrm{C}$.

Quantification of individual FAME was made by reference to a milk fat with a certified composition (CRM 164, European Community Bureau of Reference, Brussels, Belgium) according to ISO-IDF (2002b). Individual CLA isomers were identified by comparison to standard mixtures distributed by Nu-Chek Prep Inc. (Elysian, MN); GLC-461 from Nu-Chek Prep was also used to identify other FA.

\section{Statistical Analyses}

Data were analyzed using the MIXED procedure of SAS Institute (2004), with period and treatment as fixed effects and the animal as random effect. Tukey's test was used to compare least squares means. Statistical significance was declared at $P<0.05$.

\section{RESULTS AND DISCUSSION}

Dry matter intake of concentrate was about $15 \%$ lower than expected (Table 2). The observed intake of oil added to the basal diet was short of the target (48 g/d; Table 1) but equal for the 3 oils: 41.4, 40.3, and $40.0 \mathrm{~g} / \mathrm{d}(\mathrm{SEM}=1.4)$, in HOSFO, RSFO, and LO treatments, respectively. The expected response to fat sources rich in unsaturated FA should be the result of digestive effects, metabolic effects, or both. The digestive effects remain unclear (Silva et al., 2007), whereas metabolic effects of fat supplementation on DMI have not been studied extensively in goats. The limited information found in the literature (Teh et al., 1994; Brown-Crowder et al., 2001) suggests that these effects are reduced in goats compared with cows (Drackley et al., 2007). The amounts of added fat needed to depress DMI, expressed as grams per day of fat per kilogram of BW, were 3.6 and 2.4 (calculated from data of Teh et al., 1994, and Brown-Crowder et al., 2001) for goats but only 1.5 for cows (calculated from data of Drackley et al., 2007).

Results of productive performance are shown in Table 2. No significant differences were found in BW, DMI, milk content of protein and lactose, and milk yield of fat and protein. Chilliard et al. (2003) summarized the effect of fat supplementation on mid-lactation goats as having no effect on milk yield, increasing milk fat content and yield, and having no effect on milk protein content and yield. In our study, HOSFO treatment resulted in greater milk yield and lesser fat content than the LO treatment, differences that could be due to higher and lower numerical intake of concentrate and hay, respectively, in the HOSFO treatment. Nevertheless, milk fat yield and energy secreted in milk were not different between treatments (Table 2).

We did not find any significant differences in the renneting properties of milk (Table 2). This could be explained by the lack of changes in milk protein content between treatments because protein content is positively correlated to rennet clotting time and curd firmness in goat milk (Zumbo et al., 2004; Todaro et al., 2005). The relationship between milk fat content 
Table 2. Body weight, DMI, and milk yield, composition, and coagulation properties in goats receiving diets supplemented with different plant oils

\begin{tabular}{|c|c|c|c|c|c|}
\hline \multirow[b]{2}{*}{ Item } & \multicolumn{4}{|c|}{$\operatorname{Diet}^{1}$} & \multirow[b]{2}{*}{ SEM } \\
\hline & Control & HOSFO & RSFO & $\mathrm{LO}$ & \\
\hline $\mathrm{BW}, \mathrm{kg}$ & 47.2 & 47.1 & 46.8 & 46.6 & 0.5 \\
\hline \multicolumn{6}{|l|}{ DMI, g/d } \\
\hline Total & 1,409 & 1,373 & 1,343 & 1,354 & 29 \\
\hline Alfalfa hay & 404 & 403 & 395 & 420 & 8 \\
\hline Concentrate & 1,000 & 970 & 948 & 935 & 25 \\
\hline \multicolumn{6}{|l|}{ Milk } \\
\hline Yield, g/d & $1,256^{\mathrm{ab}}$ & $1,420^{\mathrm{a}}$ & $1,305^{\mathrm{ab}}$ & $1,220^{\mathrm{b}}$ & 65.2 \\
\hline Milk energy, ${ }^{2} \mathrm{kcal} / \mathrm{d}$ & 1,299 & 1,438 & 1,386 & 1,323 & 58 \\
\hline \multicolumn{6}{|l|}{ Composition, $\%$} \\
\hline Fat & $6.25^{\mathrm{b}}$ & $6.25^{\mathrm{b}}$ & $6.79^{\mathrm{a}}$ & $6.83^{\mathrm{a}}$ & 0.19 \\
\hline Protein & 3.86 & 3.79 & 3.88 & 3.94 & 0.07 \\
\hline Lactose & 4.66 & 4.71 & 4.74 & 4.67 & 0.03 \\
\hline \multicolumn{6}{|l|}{ Yield, g/d } \\
\hline Fat & 74.8 & 82.1 & 80.6 & 78.6 & 3.3 \\
\hline Protein & 46.3 & 50.4 & 47.4 & 45.1 & 2.1 \\
\hline Lactose & $57.1^{\mathrm{b}}$ & $65.7^{\mathrm{a}}$ & $60.5^{\mathrm{ab}}$ & $55.9^{\mathrm{b}}$ & 3.1 \\
\hline \multicolumn{6}{|l|}{ Coagulation properties } \\
\hline $\mathrm{pH}$ & 6.70 & 6.72 & 6.70 & 6.73 & 0.01 \\
\hline Clotting time, $\min$ & 23.3 & 23.9 & 22.2 & 23.9 & 0.8 \\
\hline Rate of curd formation, min & 4.7 & 7.6 & 6.2 & 6.4 & 0.7 \\
\hline Curd firmness, mm & 20.4 & 21.3 & 21.6 & 19.5 & 1.5 \\
\hline
\end{tabular}

a,b In a row, means without a common superscript letter differ significantly $(P<0.05)$.

${ }^{1}$ Control $=$ diet with no added oil; HOSFO, RSFO, and LO = diets enriched with $48 \mathrm{~g} / \mathrm{d}$ of high oleic sunflower oil, regular sunflower oil, or linseed oil, respectively.

${ }^{2}$ Milk energy: $\left[\left(\right.\right.$ fat $\left.\left._{\%} \times 117.7\right)+312.9\right] \times$ milk yield $_{\mathrm{kg} / \mathrm{d}}$, according to Morand-Fehr and Sauvant (1978).

and milk coagulation properties is less clear. Although Zumbo et al. (2004) reported a positive correlation between milk fat content and rennet clotting time, other authors (Todaro et al., 2005) showed a negative correlation between these parameters and between fat percentage and rate of curd formation. The effect of oil addition on renneting properties of goat milk has been scarcely studied. To our knowledge, only Mele et al. (2005) evaluated renneting properties and did not find differences in the coagulation properties in goat milk when feeding $100 \mathrm{~g} / \mathrm{d}$ soybean oil per animal.

Goat milk FA profiles of the experimental diets are shown in Table 3. The contents of 4:0, 6:0, and 8:0 in milk fat were not modified with oil supplementation, whereas 12:0, 14:0, and 16:0 decreased in milk fat of goats fed the oil-supplemented diets compared with those receiving the control diet (Table 3). Capric acid (10:0) was in an intermediate position because it decreased only in the HOSFO treatment. Vlaeminck et al. (2006), working with dairy cows, related the rumen production of individual substrates (acetic, propionic, and butyric acids) for mammary synthesis of short- and medium-chain FA to the proportion of certain odd- and branched-chain FA in milk fat. Using their equation [acetate $(\mathrm{mmol} / \mathrm{mol})=666+352 \times 14: 0$ iso +133 $\times 15: 0$ iso $-26.5 \times 15: 0-48.0 \times(17: 0+$ cis- $9-17: 1)$; FA in $\mathrm{g} / 100 \mathrm{~g}$ of fat)] and our data (Table 3), we can determine that the proportion of acetic acid in rumen fluid was $648,653,659$, and $656 \mathrm{mmol} / \mathrm{mol}$ of total VFA in control, HOSFO, RSFO, and LO treatments, respectively. These small differences do not support the hypothesis of a lack of substrate for synthesis of short- and medium-chain SFA when oil-supplemented diets were fed. A significant decrease in contents of 12:0, 14:0, and 16:0 without changes in 4:0, 6:0, and 8:0 levels in milk fat is a frequent observation in goats fed supplemental plant lipids (Bernard et al., 2005; Bouattour et al., 2008). This finding could be the result of the supply of long-chain FA to the mammary gland on the ratio of acetyl-CoA carboxylase to FA synthetase activities. Results of in vitro research (Bauman and Davis, 1974) showed that altering the ratio of acetyl-CoA carboxylase to FA synthetase activities in the mammary cell shifts the pattern of FA synthesized toward the shorter chain types when the ratio decreases. The results of Bernard et al. (2009a), who reported values of acetyl-CoA carboxylase and FA synthetase activities in the udder of goats fed diets including sunflower or linseed oil, also point in that direction.

We observed a higher content of 10-keto-18:0 in the HOSFO treatment compared with the other 3 treatments (Table 3). From in vitro results, Jenkins et al. (2006) concluded that the presence of this FA in the rumen is related to dietary oleic acid but not to lin- 
Table 3. Milk fatty acid profile (g/100 g of fatty acid methyl esters) in goats receiving diets supplemented with different plant oils

\begin{tabular}{|c|c|c|c|c|c|}
\hline \multirow[b]{2}{*}{ Fatty acid $^{1}$} & \multicolumn{4}{|c|}{ Treatment $^{2}$} & \multirow[b]{2}{*}{ SEM } \\
\hline & Control & HOSFO & RSFO & $\mathrm{LO}$ & \\
\hline \multicolumn{6}{|l|}{ SFA } \\
\hline 4:0 & 2.43 & 2.50 & 2.47 & 2.47 & 0.041 \\
\hline $5: 0$ & $0.025^{\mathrm{a}}$ & $0.023^{\mathrm{ab}}$ & $0.021^{\mathrm{ab}}$ & $0.019^{\mathrm{b}}$ & 0.001 \\
\hline $6: 0$ & 2.71 & 2.77 & 2.82 & 2.81 & 0.047 \\
\hline $7: 0$ & 0.046 & 0.042 & 0.040 & 0.036 & 0.003 \\
\hline $8: 0$ & 2.95 & 3.04 & 3.17 & 3.17 & 0.058 \\
\hline 4-Methyloctanoate & $0.047^{\mathrm{a}}$ & $0.039^{\mathrm{ab}}$ & $0.037^{\mathrm{ab}}$ & $0.037^{\mathrm{b}}$ & 0.003 \\
\hline $9: 0$ & $0.102^{\mathrm{a}}$ & $0.090^{\mathrm{ab}}$ & $0.085^{\mathrm{ab}}$ & $0.075^{\mathrm{b}}$ & 0.006 \\
\hline $10: 0$ & $11.09^{\mathrm{a}}$ & $10.09^{\mathrm{b}}$ & $10.50^{\mathrm{ab}}$ & $10.55^{\mathrm{ab}}$ & 0.158 \\
\hline Methyldecanoate & $0.078^{\mathrm{a}}$ & $0.055^{\mathrm{b}}$ & $0.054^{\mathrm{b}}$ & $0.053^{\mathrm{b}}$ & 0.005 \\
\hline $12: 0$ & $5.26^{\mathrm{a}}$ & $3.93^{\mathrm{b}}$ & $4.18^{\mathrm{b}}$ & $4.30^{\mathrm{b}}$ & 0.129 \\
\hline Methyldodecanoate & $0.026^{\mathrm{a}}$ & $0.021^{\mathrm{ab}}$ & $0.020^{\mathrm{b}}$ & $0.021^{\mathrm{ab}}$ & 0.001 \\
\hline 13:0 iso & 0.018 & 0.018 & 0.017 & 0.016 & 0.001 \\
\hline 13:0 anteiso & $0.076^{\mathrm{a}}$ & $0.043^{\mathrm{b}}$ & $0.047^{\mathrm{b}}$ & $0.052^{\mathrm{b}}$ & 0.004 \\
\hline 14:0 iso & $0.052^{\mathrm{a}}$ & $0.043^{\mathrm{b}}$ & $0.047^{\mathrm{ab}}$ & $0.044^{\mathrm{ab}}$ & 0.001 \\
\hline $14: 0$ & $10.35^{\mathrm{a}}$ & $8.61^{\mathrm{b}}$ & $9.03^{\mathrm{b}}$ & $8.81^{\mathrm{b}}$ & 0.155 \\
\hline Methyltetradecanoate & $0.069^{\mathrm{a}}$ & $0.046^{\mathrm{b}}$ & $0.044^{\mathrm{b}}$ & $0.043^{\mathrm{b}}$ & 0.004 \\
\hline $15: 0$ iso & $0.136^{\mathrm{a}}$ & $0.118^{\mathrm{b}}$ & $0.132^{\mathrm{ab}}$ & $0.119^{\mathrm{ab}}$ & 0.003 \\
\hline 15:0 anteiso & $0.277^{\mathrm{a}}$ & $0.237^{\mathrm{b}}$ & $0.232^{\mathrm{b}}$ & $0.234^{\mathrm{b}}$ & 0.007 \\
\hline $15: 0$ & $0.909^{\mathrm{a}}$ & $0.717^{\mathrm{b}}$ & $0.692^{\mathrm{b}}$ & $0.667^{\mathrm{b}}$ & 0.026 \\
\hline 16:0 iso & 0.136 & 0.146 & 0.110 & 0.107 & 0.009 \\
\hline $16: 0$ & $32.57^{\mathrm{a}}$ & $24.72^{\mathrm{b}}$ & $24.31^{\mathrm{b}}$ & $24.71^{\mathrm{b}}$ & 0.621 \\
\hline $17: 0$ & 0.393 & 0.354 & 0.330 & 0.330 & 0.010 \\
\hline 18:0 iso & $0.040^{\mathrm{ab}}$ & $0.032^{\mathrm{bc}}$ & $0.043^{\mathrm{a}}$ & $0.027^{\mathrm{c}}$ & 0.002 \\
\hline 10-keto-18:0 & $0.046^{\mathrm{b}}$ & $0.350^{\mathrm{a}}$ & $0.103^{\mathrm{b}}$ & $0.120^{\mathrm{b}}$ & 0.025 \\
\hline $18: 0$ & $5.08^{\mathrm{c}}$ & $9.37^{\mathrm{a}}$ & $8.59^{\mathrm{ab}}$ & $8.02^{\mathrm{b}}$ & 0.318 \\
\hline 19:0 & $0.012^{\mathrm{b}}$ & $0.012^{\mathrm{b}}$ & $0.012^{\mathrm{b}}$ & $0.043^{\mathrm{a}}$ & 0.002 \\
\hline $20: 0$ & $0.116^{\mathrm{b}}$ & $0.152^{\mathrm{a}}$ & $0.143^{\mathrm{a}}$ & $0.112^{\mathrm{b}}$ & 0.003 \\
\hline 21:0 & 0.025 & 0.025 & 0.022 & 0.023 & 0.001 \\
\hline $22: 0$ & $0.050^{\mathrm{b}}$ & $0.081^{\mathrm{a}}$ & $0.078^{\mathrm{a}}$ & $0.043^{\mathrm{b}}$ & 0.003 \\
\hline \multicolumn{6}{|l|}{ MUFA } \\
\hline c9-10:1/12:0 iso/11:0 & $0.448^{\mathrm{a}}$ & $0.348^{\mathrm{b}}$ & $0.360^{\mathrm{b}}$ & $0.358^{\mathrm{b}}$ & 0.015 \\
\hline$c 9-12: 1 / 13: 0$ & $0.259^{\mathrm{a}}$ & $0.166^{\mathrm{b}}$ & $0.175^{\mathrm{b}}$ & $0.182^{\mathrm{b}}$ & 0.011 \\
\hline$c 9-14: 1$ & $0.268^{\mathrm{a}}$ & $0.154^{\mathrm{b}}$ & $0.177^{\mathrm{b}}$ & $0.180^{\mathrm{b}}$ & 0.012 \\
\hline$c 9-15: 1$ & $0.052^{\mathrm{a}}$ & $0.040^{\mathrm{b}}$ & $0.039^{\mathrm{b}}$ & $0.043^{\mathrm{ab}}$ & 0.002 \\
\hline$t 8-16: 1$ & $0.051^{\mathrm{b}}$ & $0.082^{\mathrm{a}}$ & $0.079^{\mathrm{a}}$ & $0.072^{\mathrm{a}}$ & 0.004 \\
\hline t9-16:1/17:0 iso & $0.331^{\mathrm{b}}$ & $0.372^{\mathrm{b}}$ & $0.602^{\mathrm{a}}$ & $0.602^{\mathrm{a}}$ & 0.025 \\
\hline$c 7-16: 1$ & $0.241^{\mathrm{b}}$ & $0.291^{\mathrm{a}}$ & $0.255^{\mathrm{b}}$ & $0.262^{\mathrm{ab}}$ & 0.007 \\
\hline$c 8-16: 1$ & $0.012^{\mathrm{b}}$ & $0.010^{\mathrm{b}}$ & $0.014^{\mathrm{b}}$ & $0.028^{\mathrm{a}}$ & 0.001 \\
\hline c9-16:1/17:0 anteiso & $1.50^{\mathrm{a}}$ & $0.959^{\mathrm{b}}$ & $0.933^{\mathrm{b}}$ & $0.966^{\mathrm{b}}$ & 0.045 \\
\hline$c 13-16: 1$ & $0.340^{\mathrm{a}}$ & $0.179^{\mathrm{b}}$ & $0.206^{\mathrm{b}}$ & $0.220^{\mathrm{b}}$ & 0.014 \\
\hline$c 9-17: 1$ & $0.234^{\mathrm{a}}$ & $0.167^{\mathrm{b}}$ & $0.145^{\mathrm{b}}$ & $0.159^{\mathrm{b}}$ & 0.009 \\
\hline$t 4-18: 1$ & $0.014^{\mathrm{c}}$ & $0.042^{\mathrm{a}}$ & $0.025^{\mathrm{b}}$ & $0.021^{\mathrm{bc}}$ & 0.002 \\
\hline$t 5-18: 1$ & $0.014^{\mathrm{c}}$ & $0.040^{\mathrm{a}}$ & $0.023^{\mathrm{b}}$ & $0.019^{\mathrm{bc}}$ & 0.002 \\
\hline$t 6 / t 7 / t 8-18: 1$ & $0.160^{\mathrm{c}}$ & $0.479^{\mathrm{a}}$ & $0.312^{\mathrm{b}}$ & $0.293^{\mathrm{b}}$ & 0.021 \\
\hline$t 9-18: 1$ & $0.195^{\mathrm{b}}$ & $0.386^{\mathrm{a}}$ & $0.357^{\mathrm{a}}$ & $0.336^{\mathrm{a}}$ & 0.015 \\
\hline$t 10-18: 1$ & $0.336^{\mathrm{b}}$ & $0.645^{\mathrm{a}}$ & $0.543^{\mathrm{ab}}$ & $0.372^{\mathrm{b}}$ & 0.043 \\
\hline$t 11-18: 1$ & $0.977^{\mathrm{c}}$ & $1.99^{\mathrm{b}}$ & $3.59^{\mathrm{a}}$ & $3.54^{\mathrm{a}}$ & 0.241 \\
\hline$t 12-18: 1$ & $0.178^{\mathrm{b}}$ & $0.365^{\mathrm{a}}$ & $0.291^{\mathrm{a}}$ & $0.340^{\mathrm{a}}$ & 0.019 \\
\hline$c 9-18: 1$ & $15.11^{\mathrm{c}}$ & $21.35^{\mathrm{a}}$ & $18.32^{\mathrm{ab}}$ & $17.34^{\mathrm{bc}}$ & 0.653 \\
\hline$t 15 / c 11-18: 1$ & $0.313^{\mathrm{b}}$ & $0.327^{\mathrm{b}}$ & $0.327^{\mathrm{b}}$ & $0.475^{\mathrm{a}}$ & 0.019 \\
\hline$c 12-18: 1$ & $0.121^{\mathrm{c}}$ & $0.094^{\mathrm{c}}$ & $0.227^{\mathrm{b}}$ & $0.364^{\mathrm{a}}$ & 0.023 \\
\hline$c 13-18: 1$ & $0.042^{\mathrm{b}}$ & $0.041^{\mathrm{b}}$ & $0.047^{\mathrm{ab}}$ & $0.053^{\mathrm{a}}$ & 0.002 \\
\hline$t 16 / c 14-18: 1$ & $0.163^{\mathrm{c}}$ & $0.229^{\mathrm{b}}$ & $0.264^{\mathrm{b}}$ & $0.401^{\mathrm{a}}$ & 0.015 \\
\hline$c 15-18: 1$ & $0.055^{\mathrm{b}}$ & $0.066^{\mathrm{b}}$ & $0.076^{\mathrm{b}}$ & $0.293^{\mathrm{a}}$ & 0.018 \\
\hline$c 16-18: 1$ & $0.020^{\mathrm{b}}$ & $0.026^{\mathrm{ab}}$ & $0.026^{\mathrm{ab}}$ & $0.034^{\mathrm{a}}$ & 0.001 \\
\hline$c 11-20: 1$ & $0.048^{\mathrm{b}}$ & $0.069^{\mathrm{a}}$ & $0.071^{\mathrm{a}}$ & $0.049^{\mathrm{b}}$ & 0.003 \\
\hline \multicolumn{6}{|l|}{ Nonconjugated C18:2 } \\
\hline$t 11 t 15-18: 2$ & $0.045^{\mathrm{b}}$ & $0.046^{\mathrm{b}}$ & $0.046^{\mathrm{b}}$ & $0.060^{\mathrm{a}}$ & 0.003 \\
\hline$t 9 t 12 / c 9 t 13 / t 8 c 12-18: 2$ & $0.168^{\mathrm{b}}$ & $0.173^{\mathrm{b}}$ & $0.208^{\mathrm{b}}$ & $0.341^{\mathrm{a}}$ & 0.013 \\
\hline$t 8 c 13-18: 2$ & $0.064^{\mathrm{b}}$ & $0.070^{\mathrm{b}}$ & $0.070^{\mathrm{b}}$ & $0.145^{\mathrm{a}}$ & 0.006 \\
\hline$c 9 t 12-18: 2$ & 0.034 & 0.036 & 0.037 & 0.045 & 0.002 \\
\hline
\end{tabular}


Table 3 (Continued). Milk fatty acid profile (g/100 g of fatty acid methyl esters) in goats receiving diets supplemented with different plant oils

\begin{tabular}{|c|c|c|c|c|c|}
\hline \multirow[b]{2}{*}{ Fatty acid $^{1}$} & \multicolumn{4}{|c|}{ Treatment $^{2}$} & \multirow[b]{2}{*}{ SEM } \\
\hline & Control & HOSFO & RSFO & $\mathrm{LO}$ & \\
\hline$t 9 c 12-18: 2$ & $0.033^{\mathrm{bc}}$ & $0.026^{\mathrm{c}}$ & $0.036^{\mathrm{ab}}$ & $0.045^{\mathrm{a}}$ & 0.002 \\
\hline$t 11 c 15-18: 2$ & $0.029^{\mathrm{b}}$ & $0.075^{\mathrm{b}}$ & $0.054^{\mathrm{b}}$ & $0.873^{\mathrm{a}}$ & 0.061 \\
\hline$c 9 c 12-18: 2$ & $1.69^{\mathrm{b}}$ & $1.30^{\mathrm{c}}$ & $2.17^{\mathrm{a}}$ & $1.49^{\mathrm{bc}}$ & 0.083 \\
\hline Other $18: 2$ & $0.075^{\mathrm{ab}}$ & $0.061^{\mathrm{bc}}$ & $0.054^{\mathrm{c}}$ & $0.087^{\mathrm{a}}$ & 0.003 \\
\hline \multicolumn{6}{|l|}{ Conjugated C18:2 } \\
\hline$c 9 t 11-18: 2$ & $0.685^{\mathrm{b}}$ & $1.04^{\mathrm{b}}$ & $1.88^{\mathrm{a}}$ & $1.68^{\mathrm{a}}$ & 0.104 \\
\hline t9c11-18:2 & $0.016^{\mathrm{b}}$ & $0.021^{\mathrm{ab}}$ & $0.024^{\mathrm{a}}$ & $0.018^{\mathrm{b}}$ & 0.001 \\
\hline$t 10 c 12-18: 2$ & $0.008^{\mathrm{b}}$ & $0.009^{\mathrm{ab}}$ & $0.011^{\mathrm{a}}$ & $0.008^{\mathrm{ab}}$ & 0.000 \\
\hline$t 11 c 13-18: 2$ & $0.013^{\mathrm{b}}$ & $0.013^{\mathrm{b}}$ & $0.014^{\mathrm{b}}$ & $0.027^{\mathrm{a}}$ & 0.001 \\
\hline$t 12 t 14-18: 2$ & $0.008^{\mathrm{b}}$ & $0.008^{\mathrm{b}}$ & $0.009^{\mathrm{b}}$ & $0.015^{\mathrm{a}}$ & 0.001 \\
\hline$t 11 t 13-18: 2$ & $0.007^{\mathrm{b}}$ & $0.008^{\mathrm{b}}$ & $0.008^{\mathrm{b}}$ & $0.015^{\mathrm{a}}$ & 0.001 \\
\hline$t 9 t 11-18: 2$ & $0.016^{\mathrm{b}}$ & $0.018^{\mathrm{b}}$ & $0.029^{\mathrm{a}}$ & $0.019^{\mathrm{b}}$ & 0.001 \\
\hline \multicolumn{6}{|l|}{ Other PUFA } \\
\hline $16: 2$ & $0.011^{\mathrm{b}}$ & $0.013^{\mathrm{b}}$ & $0.010^{\mathrm{b}}$ & $0.054^{\mathrm{a}}$ & 0.003 \\
\hline $18: 3 n-6$ & $0.029^{\mathrm{b}}$ & $0.026^{\mathrm{b}}$ & $0.024^{\mathrm{b}}$ & $0.047^{\mathrm{a}}$ & 0.002 \\
\hline $18: 3 n-3$ & $0.143^{\mathrm{b}}$ & $0.120^{\mathrm{b}}$ & $0.121^{\mathrm{b}}$ & $0.547^{\mathrm{a}}$ & 0.031 \\
\hline$c 9 t 11 t 15-18: 3$ & $0.008^{\mathrm{b}}$ & $0.008^{\mathrm{b}}$ & $0.010^{\mathrm{b}}$ & $0.042^{\mathrm{a}}$ & 0.002 \\
\hline$c 9 t 11 c 15-18: 3$ & $0.039^{\mathrm{b}}$ & $0.036^{\mathrm{b}}$ & $0.033^{\mathrm{b}}$ & $0.091^{\mathrm{a}}$ & 0.005 \\
\hline $20: 2 n-6$ & $0.013^{\mathrm{ab}}$ & $0.012^{\mathrm{b}}$ & $0.015^{\mathrm{a}}$ & $0.012^{\mathrm{ab}}$ & 0.000 \\
\hline $20: 3 n-3$ & 0.007 & 0.009 & 0.011 & 0.010 & 0.001 \\
\hline $20: 4 n-6$ & $0.141^{\mathrm{ab}}$ & $0.120^{\mathrm{bc}}$ & $0.165^{\mathrm{a}}$ & $0.113^{\mathrm{c}}$ & 0.005 \\
\hline $20: 5 n-3$ & $0.023^{\mathrm{b}}$ & $0.020^{\mathrm{b}}$ & $0.023^{\mathrm{b}}$ & $0.037^{\mathrm{a}}$ & 0.001 \\
\hline $22: 4 n-6$ & $0.027^{\mathrm{b}}$ & $0.079^{\mathrm{a}}$ & $0.035^{\mathrm{b}}$ & $0.033^{\mathrm{b}}$ & 0.005 \\
\hline $22: 5 n-3$ & $0.037^{\mathrm{ab}}$ & $0.030^{\mathrm{b}}$ & $0.032^{\mathrm{b}}$ & $0.043^{\mathrm{a}}$ & 0.001 \\
\hline $22: 6 n-3$ & 0.021 & 0.018 & 0.023 & 0.018 & 0.001 \\
\hline$\Sigma$ SFA & $75.13^{\mathrm{a}}$ & $67.68^{\mathrm{b}}$ & $67.36^{\mathrm{b}}$ & $67.06^{\mathrm{b}}$ & 0.643 \\
\hline$\Sigma$ MUFA & $21.48^{\mathrm{b}}$ & $28.92^{\mathrm{a}}$ & $27.49^{\mathrm{a}}$ & $27.00^{\mathrm{a}}$ & 0.582 \\
\hline$\Sigma$ PUFA & $3.39^{\mathrm{c}}$ & $3.39^{\mathrm{c}}$ & $5.15^{\mathrm{b}}$ & $5.92^{\mathrm{a}}$ & 0.229 \\
\hline$\Sigma$ CLA & $0.754^{\mathrm{b}}$ & $1.12^{\mathrm{b}}$ & $1.97^{\mathrm{a}}$ & $1.79^{\mathrm{a}}$ & 0.106 \\
\hline Atherogenicity index ${ }^{3}$ & $3.22^{\mathrm{a}}$ & $1.99^{\mathrm{b}}$ & $2.00^{\mathrm{b}}$ & $1.98^{\mathrm{b}}$ & 0.089 \\
\hline $\mathrm{n}-6 / \mathrm{n}-3$ PUFA & $6.80^{\mathrm{b}}$ & $6.51^{\mathrm{b}}$ & $9.47^{\mathrm{a}}$ & $2.34^{\mathrm{c}}$ & 0.405 \\
\hline$c 9-14: 1 / 14: 0+c 9-14: 1$ & $0.025^{\mathrm{a}}$ & $0.018^{\mathrm{b}}$ & $0.019^{\mathrm{b}}$ & $0.019^{\mathrm{b}}$ & 0.001 \\
\hline$c 9-18: 1 / 18: 0+c 9-18: 1$ & $0.749^{\mathrm{a}}$ & $0.692^{\mathrm{b}}$ & $0.680^{\mathrm{b}}$ & $0.679^{\mathrm{b}}$ & 0.008 \\
\hline$c 9 t 12-18: 2 / t 12-18: 1+c 9 t 12-18: 2$ & $0.170^{\mathrm{a}}$ & $0.107^{\mathrm{b}}$ & $0.124^{\mathrm{b}}$ & $0.139^{\mathrm{ab}}$ & 0.010 \\
\hline$c 9 c 12-18: 2 / c 12-18: 1+c 9 c 12-18: 2$ & $0.934^{\mathrm{a}}$ & $0.933^{\mathrm{a}}$ & $0.911^{\mathrm{a}}$ & $0.820^{\mathrm{b}}$ & 0.009 \\
\hline$c 9 t 11 c 15-18: 3 / t 11 c 15-18: 2+c 9 t 11 c 15-18: 3$ & $0.518^{\mathrm{a}}$ & $0.379^{\mathrm{b}}$ & $0.415^{\mathrm{b}}$ & $0.128^{\mathrm{c}}$ & 0.024 \\
\hline$c 9 t 11 t 15-18: 3 / t 11 t 15-18: 2+c 9 t 11 t 15-18: 3$ & $0.156^{\mathrm{b}}$ & $0.152^{\mathrm{b}}$ & $0.190^{\mathrm{b}}$ & $0.425^{\mathrm{a}}$ & 0.018 \\
\hline
\end{tabular}

${ }^{\mathrm{a}-\mathrm{c}}$ In a row, means without a common superscript letter differ significantly $(P<0.05)$.

${ }^{1} c=$ cis, $t=$ trans, $\mathrm{SFA}=$ saturated fatty acids, MUFA $=$ monounsaturated fatty acids, PUFA $=$ polyunsaturated fatty acids, CLA = conjugated linoleic acid.

${ }^{2} \mathrm{Control}=$ diet with no added oil; HOSFO, RSFO, and LO = diets enriched with $48 \mathrm{~g} / \mathrm{d}$ of high oleic sunflower oil, regular sunflower oil, or linseed oil, respectively.

${ }^{3}$ Atherogenicity index: $(12: 0+4 \times 14: 0+16: 0) /($ MUFA + PUFA $)$, according to Ulbricht and Southgate (1991).

oleic acid. In addition, in vitro assays of McKain et al. (2010) showed that both $t 10-18: 1$ and $\operatorname{cis}(\boldsymbol{c}) 9-18: 1$ are potential substrates for the formation of 10-keto-18:0.

The content of 18:0 and $c 9-18: 1$ was lower in the control treatment probably because of the lower supply of $\mathrm{C} 18 \mathrm{FA}$ in the diet (Table 3). Precursors of both FA in milk fat are 18:0 and $c 9-18: 1$ in blood plasma, which in turn are derived from dietary $\mathrm{C} 18 \mathrm{FA}$ or, when animals are in negative energy balance, from adipose tissue. The latter origin was not likely in the current study because the goats were not losing weight and the apparent transfer of C18 FA from diet to milk was less than $60 \%$ for the diets supplemented with oil. The desaturase indexes were significantly lower in oil treatments than in the control (Table 3), which, according to Chilliard and Ferlay (2004), could be due to the higher proportions of PUFA or trans FA in the udder of animals with oil-supplemented diets.

The highest concentration of $c 9-18: 1$ and 18:0 reached in the HOSFO diet would be a consequence of the higher oleic acid present in the ration and, on the other hand, due to the action of $\Delta^{9}$-desaturase in the 
mammary gland on stearic acid previously generated in the rumen. Bernard et al. (2005) found higher amounts of 18:0 plus $c 9-18: 1$ in the milk fat of dairy goats when the dietary supplement was richer in oleic instead of linoleic acid. Gómez-Cortés et al. (2008b) and Bodas et al. (2010) found similar results when feeding supplemental olive, soybean, or linseed oil compared with a control diet to dairy ewes.

The increase of some C18 trans MUFA in milk fat differed between HOSFO, RSFO, and LO treatments (Table 3 ). The content of $t 4-, t 5-$ and $t 6 / t 7 / t 8-18: 1$ in milk fat was higher in HOSFO, second in RSFO, and least (but not significantly different from that in RSFO) in the LO treatment, in the same order as the dietary supply of oleic acid, suggesting that oleic acid is the main precursor of those isomers. Mosley et al. (2002) and AbuGhazaleh et al. (2005) listed t6/t7/ t8-18:1 as originating from in vitro biohydrogenation of oleic acid. On the other hand, Jouany et al. (2007) found numerically higher in vitro levels of $t 4-$ and t5-18:1 when adding linoleic acid instead of $\alpha$-linolenic acid. A similar response to the inclusion of regular sunflower oil or linseed oil in dairy goat diets was noted by Bernard et al. (2009b). The common increase of t9- and t12-18:1 in milk fat from goats fed the diets with added oil seems to indicate that these isomers can be derived from rumen metabolism of any of the 3 main FA supplied with the oils.

Significantly higher contents of the isomers t15/ $c 11-18: 1$ were found in milk fat from goats fed the LO diet (Table 3). Because $c 11-18: 1$ is of microbial origin (Fulco, 1983) and the content of $t 15 / c 11-18: 1$ did not change except in the goats fed the LO diet, it is logical to assume that the observed response is due to an increase of $t 15-18: 1$. The fact that $t 15-18: 1$ is one of the isomers produced by biohydrogenation of $\alpha$-linolenic acid (Harfoot and Hazlewood, 1997) supports the previous assumption. Moreover, Akraim et al. (2007) reported individual values for $t 15-18: 1$ and $c 11-18: 1$ in milk fat from dairy cows fed raw or extruded linseed compared with a control diet. These authors showed that $t 15-18: 1$ increased and $c 11-18: 1$ decreased in milk fat from cows fed the lipid-supplemented diets.

The content of t10-18:1 was significantly higher in HOSFO and RSFO treatments than in LO and control treatments (Table 3 ). The greater $t 10-18: 1$ content in HOSFO treatment could be because this is the main isomer produced from isomerization of $c 9-18: 1$ by rumen microorganisms, according to AbuGhazaleh et al. (2005). Feeding dairy ruminants diets rich in fermentable carbohydrates or linoleic acid, as in the RSFO treatment, can increase the content of $t 10-18: 1$ in milk fat (Shingfield and Griinari, 2007; Gómez-Cortés et al., 2008a). This response is due to a shift in the rumen bio- hydrogenation pathways, which results in greater production of $t 10-18: 1$ from linoleic acid via $t 10 c 12-18: 2$ (Pottier et al., 2006). The biohydrogenation of 18:3n-3 is less prone to promote $t 10-18: 1$ formation than that of linoleic acid (AbuGhazaleh and Jacobson, 2007); consistent with this, the content of t10-18:1 was similar between control and LO goats (Table 3). However, the alteration of the biohydrogenation routes was not substantial because the milk fat percentage of $t 10-18: 1$ was low in all experimental treatments $(<0.7 \%$ of total FAME). The $t 11-18: 1$ content in milk fat was highest in RSFO and LO, second highest in HOSFO, and least in the control treatment (Table 3). This is to be expected because vaccenic acid is a common intermediate in the biohydrogenation pathways of linoleic and $\alpha$-linolenic acids (Bauman et al., 1999). The significantly higher t11-18:1 content of milk fat in HOSFO compared with the control treatment could be due to the isomerization of the oleic acid supplied because both diets had approximately the same amount of linoleic and $\alpha$-linolenic acids. According to AbuGhazaleh et al. (2005), vaccenic acid is the third most abundant $t-18: 1$ isomer after $t 9$ and $t 10$ derived from in vitro biohydrogenation of oleic acid.

Griinari et al. (2000) demonstrated $\Delta^{9}$-desaturation of $t-18: 1$ isomers in the udders of dairy cows. In the present work, apart from rumenic acid, we identified 2 C18 di-unsaturated FA with $c 9$ double bonds; namely, $c 9 t 12-18: 2$ and linoleic acid. These could originate from $\Delta^{9}$-desaturation of 2 identified C18 MUFA, $t 12-$ and $c 12-18: 1$. The content of isomer $t 12-18: 1$ was significantly higher in all treatments with added oil (Table 3 ) and the ratio of $c 9 t 12-18: 2$ to $t 12-18-1$ plus $c 9 t 12-18: 2$ was significantly lower in the oil treatments (Table 3 ), suggesting that $\Delta^{9}$-desaturation of $t 12-18: 1$ was inhibited. In fact, the ratio $14: 1$ to $14: 1$ plus $14: 0$, the most commonly used ratio to determine $\Delta^{9}$-desaturase activity, was significantly lower in HOSFO, RSFO, and LO diets, and similar between oil treatments (Table 3 ). On the other hand, $\Delta^{9}$-desaturation of $c 12-18: 1$, if any, was not quantitatively relevant in our experiment, because the ratio $c 9 c 12-18: 2$ to $c 12-18: 1$ plus $c 9 c 12-18: 2$ was significantly lower in the LO treatment, which had the higher level of $c 12-18: 1$ and a level of linoleic acid similar to that of the control and HOSFO treatments (Table 3). This seems to confirm that all or most of $c 9 c 12-18: 2$ in milk fat came from dietary linoleic acid that escaped unchanged from the rumen.

Rumenic acid was the major CLA isomer found in milk fat in all treatments, although it was significantly higher in RSFO and LO. Rumenic acid mainly originates in the udder from desaturation of vaccenic acid (Bauman et al., 1999), which could explain the increases of $c 9 t 11-18: 2$ in the diets with higher amounts of 
t11-18:1. In this regard, Bernard et al. (2010) provided the first estimates of in vivo endogenous synthesis of rumenic acid (63-73\% of milk rumenic acid) from vaccenic acid in goats, and showed no difference between the 2 lipid supplements (sunflower oil and sunflower plus fish oils).

The CLA isomers t9t11-18:2 and t9c11-18:2 were significantly higher in the RSFO treatment (Table 3). The isomer t9t11-18:2 results from rumen metabolism of linoleic acid (Jouany et al., 2007; McKain et al., 2010) and its content in milk fat is related to the intake of linoleic acid (Collomb et al., 2004). Shingfield et al. (2005) found a strong negative correlation between the concentration of $t 9 c 11-18: 2$ in milk fat and milk fat content in dairy cows, and Perfield et al. (2007) demonstrated that this CLA isomer could induce milk fat depression in dairy cows. This response was not observed in the present work (Table 2) likely because of the very low amounts measured in milk fat.

Inclusion of fat sources rich in $\alpha$-linolenic acid in dairy ruminant diets leaves a relatively wide set of isomers in milk fat (Collomb et al., 2004; Bernard et al., 2009b; Gómez-Cortés et al., 2009a). These isomers have been tentatively grouped according to certain proposed rumen biohydrogenation pathways of $\alpha$-linolenic acid (Collomb et al., 2004; Destaillats et al., 2005; Gómez-Cortés et al., 2009b). The group of isomers $c 9 t 11 c 15-18: 3, t 11 c 15-18: 2$, and $c 15-18: 1$ (Table 3 ) belongs to a rumen biohydrogenation pathway proposed by Harfoot and Hazlewood (1997). These isomers have been measured in plasma of dairy cows fed either raw or extruded linseed (Akraim et al., 2007), which implies that all of them originate in the rumen; however, at least in theory, the isomer $c 9 t 11 c 15-18: 3$ also could originate from mammary $\Delta^{9}$-desaturation of $t 11 c 15-18: 2$. Nevertheless, the ratio $c 9 t 11 c 15-18: 3$ to $t 11 c 15-18: 2$ plus $c 9 t 11 c 15-18: 3$ calculated from our data (Table 3) and that of Gómez-Cortés et al. (2009b) and Bodas et al. (2010) does not support that mammary $\Delta^{9}$-desaturation of $t 11 c 15-18: 2$ is the main source of $c 9 t 11 c 15-18: 3$, because, in all 3 studies, the ratio was much higher in the control diet than in the 18:3n-3-enriched diet $(0.52$ vs. $0.13,0.50$ vs. 0.16 , and 0.30 vs. 0.13 , respectively). On the other hand, mammary $\Delta^{9}$-desaturation could convert $t 11 t 15-18: 2$ to $c 9 t 11 t 15-18: 3$. Although in Bodas et al. (2010), the ratio $c 9 t 11 t 15-18: 3$ to $t 11 t 15-18: 2$ plus $c 9 t 11 t 15-18: 3$ was similar (0.29 in linseed oil vs. 0.33 in control diet), in the present work (Table 3 ) and that of Gómez-Cortés et al. (2009b), the ratio was much higher in 18:3n-3-rich diets than in control diets (0.43 vs. 0.16 and 0.39 vs. 0.14 , respectively, in our study and that of Gómez-Cortés et al., 2009b), despite the fact that common desaturase indexes (Table 3) were higher in the control diet, at least in our study. To our knowledge, the isomer $c 9 t 11 t 15-18: 3$ has not yet been described in rumen effluent, plasma, or in the products of in vitro rumen metabolism of $\alpha$-linolenic acid. The hypothesis of mammary $\Delta^{9}$-desaturation of $t 11 t 15-18: 2$ does not preclude the existence of a rumen biohydrogenation pathway involving $c 9 t 11 t 15-18: 3, t 11 t 15-18: 2$, and $t 15-18: 1$, as postulated by Gómez-Cortés et al. (2009b), but it would imply that the $c 9$ double bond of $c 9 t 11 t 15-18: 3$ is hydrogenated in the rumen, rendering t11t15-18:2.

Unsaturated FA with a double bond at carbon 13 can be considered specific to $\alpha$-linolenic rumen metabolism (Jouany et al., 2007). Collomb et al. (2004) stated that the content of the CLA isomers $t 11 \mathrm{c} 13-$, t11t13-, and $c 11 t 13-18: 2$ (and also t12t14-18:2) in the milk fat of dairy cows is positively correlated with the daily intake of $\alpha$-linolenic acid. In our experiment, the first 2 isomers and $t 12 t 14-18: 2$ were identified (Table 3 ) and their content in milk fat was significantly higher in the LO treatment. Also, Luna et al. (2008) and Bernard et al. (2009b) with goats, and Gómez-Cortés et al. (2009b) and Bodas et al. (2010) with ewes, found higher proportions of these isomers in milk fat with 18:3n-3-enriched diets. Kraft et al. (2003) suggested that $t 11 c 13-18: 2$ could be part of an unknown biohydrogenation pathway of $\alpha$-linolenic acid. In the present experiment (Table 3) and in that of Bodas et al. (2010), another FA, t8c13-18:2, increased significantly in milk fat when linseed oil was included in the diet.

The atherogenicity index was significantly reduced in all oil-supplemented diets because of a decrease in total SFA levels and an increase in the percentage of MUFA. However, only the LO treatment showed a decreased n-6:n-3 PUFA ratio (from 6.80 to 2.34). The low n6:n-3 PUFA ratio in milk fat from the LO treatment (Table 3) agrees well with the results of Nudda et al. (2007), Bodas et al. (2010), and Côrtes et al. (2010) from studies in goats, ewes, and cows, respectively. It is recommended that the n-6:n-3 PUFA ratio be lower than 4 (Simopoulos, 2008) in fats for human consumption. The increase of the n-6:n-3 PUFA ratio in milk fat from the RSFO treatment was expected (Table 3) because it supplied the highest amount of linoleic acid to the animals (Table 1 ). The n-6:n-3 PUFA ratio in milk fat was not altered in the HOSFO treatment compared with the control treatment (Table 3), because the HOSFO treatment did not increase either the n-3 or n-6 FA content in the diet (Table 1).

\section{CONCLUSIONS}

Compared with a control diet without added oil, the inclusion of 3 differently unsaturated plant oils in the diet of dairy goats had only moderate effects on animal 
performance and reduced the milk fat content of medium-chain SFA. Diets with added linseed oil resulted in high contents of CLA and c18:3n-3 without increasing the percentage of t10-18:1. These facts, together with the lowest atherogenicity index and n-6:n-3 PUFA ratio of such treatment, suggest that dietary linseed oil is the best option to improve nutritionally the FA profile in milk fat of dairy goats.

\section{ACKNOWLEDGMENTS}

This work was financed by the Ministerio de Ciencia e Innovación (MICINN; AGL2008-04805 and Consolider Ingenio 2010 Programme; FUN-C-FOOD CSD2007063) and the Comunidad Autónoma de Madrid (2009AGR-1469). The authors thank A. Jiménez Secilla and B. Garfia Catalán of Laboratorio Agropecuario Regional of Córdoba for their help with milk composition analysis; I. Andújar-Ramírez (Universidad de Córdoba, Córdoba, Spain) and M. V. Rodríguez-Pino (CSIC, Madrid, Spain) for their technical assistance in processing milk samples; and J. J. Pérez-Hernández (Universidad de Córdoba, Córdoba, Spain) for his assistance in animal feeding and management.

\section{REFERENCES}

AbuGhazaleh, A. A., and B. N. Jacobson. 2007. The effect of $\mathrm{pH}$ and polyunsaturated $\mathrm{C} 18$ fatty acid source on the production of vaccenic acid and conjugated linoleic acids in ruminal cultures incubated with docosahexaenoic acid. Anim. Feed Sci. Technol. 136:11-22.

AbuGhazaleh, A. A., M. B. Riley, E. E. Thies, and T. C. Jenkins. 2005. Dilution rate and $\mathrm{pH}$ effects on the conversion of oleic acid to trans C18:1 positional isomers in continuous culture. J. Dairy Sci. 88:4334-4341.

Akraim, F., M. C. Nicot, P. Juaneda, and F. Enjalbert. 2007. Conjugated linolenic acid (CLnA), conjugated linoleic acid (CLA) and other biohydrogenation intermediates in plasma and milk fat of cows fed raw or extruded linseed. Animal 1:835-843.

AOAC. 2006. Official Methods of Analysis. 18th ed. 1st rev. AOAC Int., Gaithersburg, MD.

Bauman, D. E., L. H. Baumgard, B. A. Corl, and J. M. Griinari. 1999. Biosynthesis of conjugated linoleic acid in ruminants. Proc. Am. Soc. Anim. Sci. Annu. Mtg. 1999. Accessed Feb. 28, 2010. http:// www.asas.org/jas/symposia/proceedings/0937.pdf.

Bauman, D. E., and C. L. Davis. 1974. Biosynthesis of milk fat. Pages 31-75 in Lactation: A Comprehensive Treatise. Volume 2. B. L. Larson and V. R. Smith, ed. Academic Press, New York, NY.

Bernard, L., M. Bonnet, C. Leroux, K. J. Shingfield, and Y. Chilliard. 2009a. Effect of sunflower-seed oil and linseed oil on tissue lipid metabolism, gene expression, and milk fatty acid secretion in Alpine goats fed maize silage-based diets. J. Dairy Sci. 92:60836094.

Bernard, L., J. Mouriot, J. Rouel, F. Glasser, P. Capitan, E. PujosGuillot, J. M. Chardigny, and Y. Chilliard. 2010. Effects of fish oil and starch added to a diet containing sunflower-seed oil on dairy goat performance, milk fatty acid composition and in vivo delta 9-desaturation of C-13 vaccenic acid. Br. J. Nutr. 104:346-354.

Bernard, L., J. Rouel, C. Leroux, A. Ferlay, Y. Faulconnier, P. Legrand, and Y. Chilliard. 2005. Mammary lipid metabolism and milk fatty acid secretion in alpine goats fed plant lipids. J. Dairy Sci. $88: 1478-1489$.
Bernard, L., K. J. Shingfield, J. Rouel, A. Ferlay, and Y. Chilliard. 2009b. Effect of plant oils in the diet on performance and milk fatty acid composition in goats fed diets based on grass hay or maize silage. Br. J. Nutr. 101:213-224.

Bodas, R., T. Manso, A. R. Mantecón, M. Juárez, M. A. de la Fuente, and P. Gómez-Cortés. 2010. Comparison of the fatty acid profiles in cheeses from ewes fed diets supplemented with different plant oils. J. Agric. Food Chem. 58:10493-10502.

Bouattour, M. A., R. Casals, E. Albanell, X. Such, and G. Caja. 2008. Feeding soybean oil to dairy goats increases conjugated linoleic acid in milk. J. Dairy Sci. 91:2399-2407.

Brown-Crowder, I. E., S. P. Hart, M. Cameron, T. Sahlu, and A. L. Goetsch. 2001. Effects of dietary tallow level on performance of Alpine does in early lactation. Small Rumin. Res. 39:233-241.

Chilliard, Y., and A. Ferlay. 2004. Dietary lipids and forages interactions on cow and goat milk fatty acid composition and sensory properties. Reprod. Nutr. Dev. 44:467-492.

Chilliard, Y., A. Ferlay, R. M. Mansbridge, and M. Doreau. 2000. Ruminant milk fat plasticity: Nutritional control of saturated, polyunsaturated, trans and conjugated fatty acids. Ann. Zootech. 49:181-205.

Chilliard, Y., A. Ferlay, J. Rouel, and G. Lamberet. 2003. A review of nutritional and physiological factors affecting goat milk lipid synthesis and lipolysis. J. Dairy Sci. 86:1751-1770.

Chilliard, Y., and A. Ollier. 1994. Alimentation lipidique et métabolisme du tissu adipeux chez les ruminants. Comparaison avec le porc et les rongeurs. INRA Prod. Anim. 7:293-308.

Collomb, M., R. Sieber, and U. Bütikofer. 2004. CLA isomers in milk fat from cows fed diets with high levels of unsaturated fatty acids. Lipids 39:355-364.

Combe, N., P. Clouet, J. M. Chardigny, M. Lagarde, and C. L. Léger. 2007. Trans fatty acids, conjugated linoleic acids, and cardiovascular diseases. Eur. J. Lipid Sci. Technol. 109:945-953.

Côrtes, C., D. C. da Silva-Kazama, R. Kazama, N. Gagnon, C. Benchaar, G. T. D. Santos, L. M. Zeoula, and H. V. Petit. 2010. Milk composition, milk fatty acid profile, digestion, and ruminal fermentation in dairy cows fed whole flaxseed and calcium salts of flaxseed oil. J. Dairy Sci. 93:3146-3157.

Destaillats, F., J. P. Trottier, J. M. G. Galvez, and P. Angers. 2005. Analysis of $\alpha$-linolenic acid biohydrogenation intermediates in milk fat with emphasis of conjugated linolenic acids. J. Dairy Sci. 88:3231-3239.

Drackley, J. K., T. R. Overton, G. Ortiz-Gonzalez, A. D. Beaulieu, D. M. Barbano, J. M. Lynch, and E. G. Perkins. 2007. Responses to increasing amounts of high-oleic sunflower fatty acids infused into the abomasum of lactating dairy cows. J. Dairy Sci. 90:51655175 .

Field, C. J., H. H. Blewett, S. Proctor, and D. Vine. 2009. Human health benefits of vaccenic acid. Appl. Physiol. Nutr. Metab. 34:979-991.

Fulco, A. J. 1983. Fatty acid metabolism in bacteria. Prog. Lipid Res. $22: 133-160$.

Gómez-Cortés, P., A. Bach, P. Luna, M. Juárez, and M. A. de la Fuente. 2009a. Extruded linseed on ewes rations improves omega-3 fatty acids and conjugated linoleic acid contents in cheese and milk fat. J. Dairy Sci. 92:4122-4134.

Gómez-Cortés, P., P. Frutos, A. R. Mantecón, M. Juárez, M. A. de la Fuente, and G. Hervás. 2008a. Milk production, conjugated linoleic acid content, and in vitro ruminal fermentation in response to high levels of soybean oil in dairy ewe diet. J. Dairy Sci. 91:1560-1569.

Gómez-Cortés, P., P. Frutos, A. R. Mantecón, M. Juárez, M. A. de la Fuente, and G. Hervás. 2008b. Addition of olive oil to dairy ewe diets: Effect on milk fatty acid profile and animal performance. J. Dairy Sci. 91:3119-3127.

Gómez-Cortés, P., C. Tyburczy, J. T. Brenna, M. Juárez, and M. A. de la Fuente. 2009b. Characterization of cis-9 trans-11 trans-15 C18:3 in milk fat by GC and covalent adduct chemical ionization tandem MS. J. Lipid Res. 50:2412-2420.

Griinari, J. M., B. A. Corl, S. H. Lacy, P. Y. Chouinard, K. V. V. Nurmela, and D. E. Bauman. 2000. Conjugated linoleic acid is syn- 
thesized endogenously in lactating dairy cows by $\Delta 9$ desaturase. J. Nutr. 130:2285-2291.

Harfoot, C. G., and G. P. Hazlewood. 1997. Lipid metabolism in the rumen. Pages 382-426 in The Rumen Microbial Ecosystem. P. N. Hobson, ed. Blackie Academic \& Professional, London, UK.

INRA. 2002. Tables de Composition et de Valeur Nutritive des Matières Premières Destinées aux Animaux d'Élevage. Institut National de la Recherche Agronomique, Paris, France.

ISO-IDF. 2002a. Milk fat-Preparation of fatty acid methyl esters. International Standard ISO 15884-IDF 182: 2002. International Dairy Federation, Brussels, Belgium.

ISO-IDF. 2002b. Milk fat-Determination of the fatty acid composition by gas-liquid chromatography. International Standard ISO 15885-IDF 184: 2002. International Dairy Federation, Brussels, Belgium.

Jenkins, T. C., A. A. AbuGhazaleh, S. Freeman, and E. E. Thies. 2006. The production of 10-hydroxystearic and 10-ketoestearic acids is an alternative route of oleic acid transformation by the ruminal microbiota in cattle. J. Nutr. 136:926-931.

Jouany, J. P., B. Lassalas, M. Doreau, and F. Glasser. 2007. Dynamic features of the rumen metabolism of linoleic acid, linolenic acid and linseed oil measured in vitro. Lipids 42:351-360.

Kraft, J., M. Collomb, P. Möckel, R. Sieber, and G. Jahreis. 2003. Differences in CLA isomer distribution of cow's milk lipids. Lipids 38:657-664.

Luna, P., A. Bach, M. Juárez, and M. A. de la Fuente. 2008. Effect of a diet enriched in whole linseed and sunflower oil on goat milk fatty acid composition and conjugated linoleic acid isomer profile. J. Dairy Sci. 91:20-28.

Luna, P., M. Juárez, and M. A. de la Fuente. 2005. Validation of a rapid milk fat separation method to determine the fatty acid profile by gas chromatography. J. Dairy Sci. 88:3377-3381.

MARM (Ministry of the Environment and Rural and Marine Affairs) 2010. Action Plan for Goat Milk (in Spanish). MARM, Madrid, Spain.

McKain, N., K. J. Shingfield, and R. J. Wallace. 2010. Metabolism of conjugated linoleic acids and 18:1 fatty acids by ruminal bacteria: Products and mechanisms. Microbiology 156:579-588.

Mele, M., A. Serra, M. R. Rafanelli, G. Conte, and P. Secchiari. 2005. Effect of forage/concentrate ratio and soybean oil supplementation on milk yield and quality from dairy goats. Ital. J. Anim. Sci. 4:392-394.

Morand-Fehr, P., and D. Sauvant. 1978. Nutrition and optimum performance of dairy goats. Livest. Prod. Sci. 5:203-213.

Mosley, E. E., G. L. Powell, M. B. Riley, and T. C. Jenkins. 2002 Microbial biohydrogenation of oleic acid to trans isomers in vitro. J. Lipid Res. 43:290-296.

NRC. 2007. Nutrient Requirements of Small Ruminants. National Academy Press, Washington, DC.
Nudda, A., G. Battacone, S. Fancellu, G. A. Carboni, and G. A. Pulina. 2007. The use of linseed and cottonseed to change the fatty acid profile in early lactation dairy goats. Pages 49-53 in Advanced Nutrition and Feeding Strategies to Improve Sheep and Goat Production. A. Priolo, L. Biondi, H. Ben Salem, and P. Morand-Fehr, ed. CIHEAM-IAMZ, Zaragoza, Spain.

Perfield, J. W., A. L. Lock, J. M. Griinari, A. Saebo, P. Delmonte, D. A. Dwyer, and D. E. Bauman. 2007. Trans-9,cis-11 conjugated linoleic acid reduces milk fat synthesis in lactating dairy cows. J. Dairy Sci. 90:2211-2218.

Pottier, J., M. Focant, C. Debier, G. De Buysser, C. Goffe, E. Mignolet, E. Froidmont, and Y. Larondelle. 2006. Effect of dietary vitamin $\mathrm{E}$ on rumen biohydrogenation pathways and milk fat depression in dairy cows fed high-fat diets. J. Dairy Sci. 89:685-692.

SAS Institute. 2004. SAS/STAT 9.1 User's Guide. SAS Institute Inc. Cary, NC.

Shingfield, K. J., and J. M. Griinari. 2007. Role of biohydrogenation intermediates in milk fat depression. Eur. J. Lipid Sci. Technol. 109:799-816.

Shingfield, K. J., C. K. Reynolds, B. Lupoli, V. Toivonen, M. P. Yurawecz, P. Delmonte, J. M. Griinari, A. S. Grandison, and D. E. Bauman. 2005. Effect of forage type and proportion of concentrate in the diet on milk fatty acid composition in cows given sunflower oil and fish oil. Anim. Sci. 80:225-238.

Silva, M. M. C., M. T. Rodrigues, R. H. Branco, C. A. F. Rodrigues, J. L. R. Sarmento, A. C. Queiroz, and S. P. Silva. 2007. Suplementação de lipídios em dietas para cabras em lactação: consumo e eficiência de utilização de nutrientes. R. Bras. Zootec. 36:257-267.

Simopoulos, A. P. 2008. The importance of the omega-6/omega-3 fatty acid ratio in cardiovascular disease and other chronic diseases. Exp. Biol. Med. (Maywood) 233:674-688.

Teh, T. H., L. T. Trung, Z. H. Jia, T. A. Gipson, K. B. Ogden, and T. F. Sweeney. 1994. Varying amounts of rumen-inert fat for high producing goats in early lactation. J. Dairy Sci. 77:253-258.

Todaro, M., M. L. Scatassa, and P. Giaccone. 2005. Multivariate factor analysis of Girgentana goat milk composition. Ital. J. Anim. Sci. 4:403-410.

Ulbricht, T. L. V., and D. A. T. Southgate. 1991. Coronary heart disease: Seven dietary factors. Lancet 338:985-992.

Van Soest, P. J., J. B. Robertson, and A. Lewis. 1991. Methods for dietary fiber, neutral detergent fiber and non-starch polysaccharides in relation to animal nutrition. J. Dairy Sci. 74:3583-3597.

Vlaeminck, B., V. Fievez, S. Tamminga, R. J. Dewhurst, A. van Vuuren, D. De Brabander, and D. Demeyer. 2006. Milk odd- and branched-chain fatty acids in relation to the rumen fermentation pattern. J. Dairy Sci. 89:3954-3964.

Zumbo, A., B. Chiofalo, L. Liotta, A. Rundo Sotera, and V. Chiofalo. 2004. Quantitative and qualitative milk characteristics of Nebrodi goats. S. Afr. J. Anim. Sci. 34:155-157. 